\title{
Evaluation of Safflower Genotypes against Major Disease Alternaria Leaf Spot of Safflower
}

\author{
N. M. Prabhavathi* \\ Agricultural Research Station Annigeri, University of Agricultural Science Dharwad, India \\ *Corresponding author
}

\begin{tabular}{l} 
K e y w o r d s \\
Safflower, \\
Alternaria leafspot, \\
Genotype \\
Article Info \\
$\begin{array}{l}\text { Accepted: } \\
26 \text { August } 2020 \\
\text { Available Online: } \\
\text { 10 September } 2020\end{array}$ \\
\hline
\end{tabular}

Keywords

Safflower,

Alternaria leafspot,

Genotype

Article Info

Accepted:

Available Online

10 September 2020

\section{A B S T R A C T}

Safflower (Carthamus tinctorius L.) is one of the most important oilseed crops of the world valued for its highly nutritious edible oil. It is a multipurpose crop having various uses like source of edible oil, cattle feed, medicinal and industrial products. The leaf spot disease caused by Alternaria carthami Chowdhary is a major destructive disease of safflower (Carthamus tinctorius L.) in India. The disease has been reported to cause seed yield losses to the tune of 10 to 25 per cent. Under severe conditions, it has been reported to cause 50 per cent loss in seed yield 34 germplasm accessions were screened for the identification of resistance or even tolerance for the disease. The incidence of Alternaria leaf spot was observed in the field under natural conditions. Accessions were grouped based on 0 to 9 disease rating scale. Five accessions showed resistant reaction with grade 3 and eighteen accessions showed moderately resistant (MR) reaction with grade 5 and seven genotypes showed susceptible reaction with grade 7 .

\section{Introduction}

Safflower (Carthamus tinctorius L.) occupies prominent place in the agricultural wealth and economy of India. It belongs to family Compositae and believes to be native of Afganistan. The word Carthamus is Arabic word quartum (means the colour of dye obtained from florets). It is described as "Kusumbha" in ancient Sanskrit literature.
Other Indian names, like Kusum, Karrad (Hindi), Kusumpuli (Bengali), Kusumbo (Gujrathi), Kardi, Kurdi (Marathi), Sendurakam (Tamil), Kusuma (Telgu), Kusube, Kusume (Kannada), Kusumba (Punjabi) seem to have been derived from "Kusumbha". Presently the most common name being "Kusum" or "Kardi". It is a rich source of proteins and edible oil and so many farmers plant it. 
Safflower (Carthamus tinctorius L.) is one of the most important oilseed crops of the world valued for its highly nutritious edible oil. It is a multipurpose crop having various uses like source of edible oil, cattle feed, medicinal and industrial products.

Safflower is known to suffer from many fungal and bacterial diseases among them seed borne disease viz., Alternaria leaf spot/blight (ALS) caused by Alternaria carthami and soil borne diseases viz., wilt (Fusarium oxysporum f.sp. carthami) and Phytophthora blight (Phytophthora carthami) are major and attack at different stages of crop growth (Bhale et al., 1998).

The leaf spot disease caused by Alternaria carthami Chowdhary is a major destructive disease of safflower (Carthamus tinctorius L.) in India. The disease has been reported to cause seed yield losses to the tune of 10 to 25 per cent (Indi et al., 1988). Under severe conditions, it has been reported to cause 50 per cent loss in seed yield (Indi et al., 1986). Safflower plant is also prone to infection by several seed-borne fungi (Ramesh and Avitha, 2005). Seeds also act as carrier in transmission of pathogens and thereby cause economic threat to safflower cultivation. Considering the economic losses in this present investigation attempts were therefore made to screen out the resistant sources against the Alternaria leaf spot disease.

\section{Materials and Methods}

The experiment was carried out at Agricultural Research Station, Annigeri, University of Agricultural Sciences, Dharwad during rabi 2017-18. The research station is situated in the northern dry zone of Karnataka between $15^{\circ} 8^{\prime} \mathrm{N}$ latitude, $75^{\circ} 3^{\prime} \mathrm{E}$ longitude and at an altitude of 624.80 meters above the mean sea level. The experimental material for the present study comprised of 34 safflower germplasm accessions obtained from the
Germplasm Unit of the Directorate of Oilseeds Research, Hyderabad. Disease screening for Alternaria was done under field condition. Methodology as followed as below.

The crop was sown using randomized block design with single row system. Each genotype was planted with $45 \mathrm{~cm}$ row spacing and 20 $\mathrm{cm}$ between the plants. Recommended agronomic practices and insect pest control measures were followed as per the package of practices of University of Agricultural Sciences, Dharwad, Karnataka. The observations were recorded on ten plant basis, selected randomly from each replication of the individual genotype for percent disease index (PDI). The disease severity was recorded at flowering stage and harvesting stage following standard disease scoring scale (Mayee and Datar, 1986). Further, the materials were categorized as highly resistant, resistant, moderately resistant, susceptible and highly susceptible based on 0 to 9 disease scale for Alternaria (Table 1).

\section{Results and Discussion}

In present investigation, 34 germplasm accessions were screened for the identification of resistance or even tolerance for the disease. The incidence of Alternaria leaf spot was observed in the field under natural conditions and the results are presented in table 2. Accessions were grouped based on 0 to 9 disease rating scale. Five accessions showed resistant reaction with grade 3 and eighteen accessions showed moderately resistant (MR) reaction with grade 5 and seven genotypes showed susceptible reaction with grade 7 .

The similar studies on the safflower germplasm screening against Alternaria blight (Alternaria carthami) were done earlier by several workers (Akashe, et al., 1994; Desai, 1998; Indi, et al., 2004; Relekar, 2008 and Murumkar et al., 2009). 
Table.1 Disease scoring scale to Alternaria leaf spot of safflower

\begin{tabular}{|c|c|c|}
\hline Grade & Description & Category \\
\hline $\mathbf{0}$ & No symptoms on leaves & Immune \\
\hline 1 & Small, round brown spots covering $1 \%$ or less of the leaf & Highly resistant \\
\hline 3 & Brown sunken spots covering $1-10 \%$ of the leaf area & Resistant \\
\hline 5 & $\begin{array}{l}\text { Brown spots enlarging to form circular spots covering } 11-25 \% \text { of } \\
\text { the leaf Area }\end{array}$ & Moderately resistant \\
\hline 7 & Circular, brown, sunken spots covering $26-50 \%$ of the leaf area & Susceptible \\
\hline 9 & $\begin{array}{l}\text { Circular to irregular, brown sunken spots covering } 51 \% \text { or more } \\
\text { of the leaf Area }\end{array}$ & Highly susceptible \\
\hline
\end{tabular}

Table.2 Reaction of safflower genotypes to Alternaria leaf spot during rabi 2017-18

\begin{tabular}{|c|c|c|c|}
\hline Sl.No & Germ plasma & Mean & Reaction \\
\hline $\mathbf{1}$ & SAF-1601 & 11.35 & MR \\
\hline $\mathbf{2}$ & SAF-1603 & 8.4 & R \\
\hline $\mathbf{3}$ & SAF-1606 & 13.05 & MR \\
\hline $\mathbf{4}$ & SAF-1608 & 9.1 & R \\
\hline $\mathbf{5}$ & SAF-1607 & 10.55 & MR \\
\hline $\mathbf{6}$ & SAF-1630 & 26.8 & S \\
\hline $\mathbf{7}$ & SAF-1656 & 32.2 & S \\
\hline $\mathbf{8}$ & SAF-1659 & 4.11 & R \\
\hline $\mathbf{9}$ & SAF-1660 & 16.1 & MR \\
\hline $\mathbf{1 0}$ & SAF-1685 & 10.5 & MR \\
\hline $\mathbf{1 1}$ & SAF-1689 & 30.1 & S \\
\hline $\mathbf{1 2}$ & SAF-1693 & 27.1 & S \\
\hline $\mathbf{1 3}$ & SAF-1401 & 26.7 & S \\
\hline $\mathbf{1 4}$ & SAF-1517 & 14.7 & MR \\
\hline $\mathbf{1 5}$ & SAF-1556 & 26.25 & S \\
\hline $\mathbf{1 6}$ & GMU-2757 & 30.25 & S \\
\hline $\mathbf{1 7}$ & SAF-1617 & 6.25 & R \\
\hline $\mathbf{1 8}$ & SAF-1701 & 18.9 & MR \\
\hline $\mathbf{1 9}$ & SAF-1710 & 22.0 & MR \\
\hline $\mathbf{2 0}$ & SAF-1711 & 10.5 & MR \\
\hline $\mathbf{2 1}$ & SAF-1717 & 7.8 & R \\
\hline $\mathbf{2 2}$ & SAF-1738 & 11.7 & MR \\
\hline $\mathbf{2 3}$ & PBNS-153 & 4.95 & R \\
\hline $\mathbf{2 4}$ & PBNS-154 & 8.6 & R \\
\hline $\mathbf{2 5}$ & PBNS-170 & 11 & MR \\
\hline $\mathbf{2 6}$ & PBNS-171 & 10.8 & MR \\
\hline $\mathbf{2 7}$ & PBNS-172 & 10.5 & MR \\
\hline & & & \\
\hline
\end{tabular}




\begin{tabular}{|c|c|c|c|}
\hline $\mathbf{2 8}$ & $1749-1$ & 28.1 & $\mathrm{~S}$ \\
\hline $\mathbf{2 9}$ & $3350-8$ & 23.1 & MR \\
\hline $\mathbf{3 0}$ & $3350-2$ & 11.8 & MR \\
\hline $\mathbf{3 1}$ & $1703-2$ & 10.5 & MR \\
\hline $\mathbf{3 2}$ & $3350-3$ & 10.7 & MR \\
\hline $\mathbf{3 3}$ & $1749-1-2$ & 15.9 & MR \\
\hline $\mathbf{3 4}$ & DSI-116 & 6.4 & R \\
\hline $\mathbf{3 5}$ & HUS305 & 9.05 & R \\
\hline $\mathbf{3 6}$ & Manjira & 29.1 & $\mathrm{~S}$ \\
\hline
\end{tabular}

Awadhiya (1992) identified A. carthami, Fusarium moniliforme, Botrytis cinerea, Macrophomina phaseolina, Stachybotrys spp. and Oedocephalum spp. from seeds of 50 safflower cultivars in states of Maharashtra, Karnataka, Andhra Pradesh and Madhya Pradesh in India. A. carthami was the only pathogen found in all varieties tested. In studies of healthy, discoloured, wrinkled and deformed seeds of five varieties (APRR 2, HUS 304, JSF 1, NS 99-A and SF 364) no particular association of the pathogen with the condition of seed was found. Chavan and Kakde (2009) isolated nine fungal species from safflower cultivars. Among these, Aspergillus spp. showed dominance, followed by Fusarium spp. and Alternaria spp. Bhima variety showed maximum susceptibility to fungi and got infected by Aspergillus niger. A. flavus, Fusarium oxysporum, Alternaria dianthicola and Alternaria dianthi while C1L and $\mathrm{C} 1 \mathrm{~B}$ varieties were least susceptible to fungi.

This study confirms that differences in resistance to major diseases exist in germplasm of safflower. The resistant nature of elite lines observed in present field trials confirmed the reports by Singh et al., (1987), Borkar and Shinde (1988), Zad (1992), Khanam (1993) and Ismail et al., (2004). These findings suggest that it is possible to improve an existing line through further selection and screening of the progenies of the parental line.

\section{References}

Akashe, V.B., Deokar, C.D., Veer, D.M. and Patil, M.W. 1994. Evaluation of promising safflower entries for multiple resistance to insect pests and disease. $J$. Maha. Agric. Univ., 19(3): 482-483.

Awadhiya GK (1992). Seed borne pathogenic mycoflora of safflower. Crop Res. 5(2):344-347.

Bhale MS, Bhale Usha, Khare MN (1998). Diseases of important oilseed crops and their management. In: Khurana SM Paul (ed.) Pathological problems of economic crop plants and their management, Scientific Publishers (India), Jodhpur. pp. 251-279.

Borkar SG, Shinde R (1988). Alternaria leaf spot of safflower. Seed Res. 16:126-127

Desai, S.A. 1998. A note on the preliminary screening of safflower genotypes against Alternaria leaf spot in northern Karnataka. Karnataka J. of Agri. Sci., 11(3) 824.

Indi, D.V., Murumkar, D.R., Patil, A.J. and Akash, V.B. 2004. Screening of safflower germplasm against Alternaria leaf spot under field condition. J. Maha. Agri. Uni., 29 (3): 344-346.

Khanam M (1993). Seed-borne fungi associated with safflower and their effect on germination. Sarhad J. Agric. 9:153-156.

Mayee CD, Datar VV (1986). Phytopathometry. Technical Bull-I, 
MAU, Parbhani. pp. 88-89.

Murumkar, D.R., Gud, M.A., Akashe, V.B. and Shinde, S.K. 2009. Identification of source of resistance to major disease and pest of safflower. J. Pl. Dis. Sci., 4 (2): 107- 109.

Relekar, N.N. 2008. Studies on Alternaria blight caused by Alternaria carthami in safflower. M.Sc. Thesis MKV, Parbhani.

Singh SN, Agarwal SC, Khare MN (1987). Seedborne mycoflora of safflower, their significance and control. Seed Res. 15:190-194.

Singh, V. and Prasad, R. D. 2005. Integrated management of pests and diseases in safflower. Directorate of Oilseeds Research, Hyderabad, India, pp. 49.

Zad SJ (1992). Safflower seed-borne diseases. Mededelingen van de Faculteit Landbouwwetenschappen, Universiteit Gent 57:161-163.

\section{How to cite this article:}

Prabhavathi, N.M. 2020. Evaluation of Safflower Genotypes against Major Disease Alternaria Leaf Spot of Safflower. Int.J.Curr.Microbiol.App.Sci. 9(09): 3593-3597. doi: https://doi.org/10.20546/ijcmas.2020.909.444 